\title{
KINASE INHIBITORS IN THE TREATMENT OF THYROID CANCER: INSTITUTIONAL EXPERIENCE
}

\author{
Matea Pešorda ${ }^{1}$, Sanja Kusačić Kuna ${ }^{1,3}$, Dražen Huić ${ }^{1,3}$, Davorin Hercege ${ }^{2,4}$, \\ Marija Despot ${ }^{1}$, Tatjana Samardžić ${ }^{1}$, Milena Gnjidić ${ }^{2}$ and Borislav Belev ${ }^{2,3}$ \\ ${ }^{1}$ Clinical Department of Nuclear Medicine and Radiation Protection, \\ Zagreb University Hospital Centre, Zagreb, Croatia; \\ ${ }^{2}$ Clinical Department of Oncology, Zagreb University Hospital Centre, Zagreb, Croatia; \\ ${ }^{3}$ The University of Zagreb School of Medicine, Zagreb, Croatia; \\ ${ }^{4}$ The University of Zagreb School of Dental Medicine, Zagreb, Croatia
}

\begin{abstract}
SUMMARY - Although most patients with thyroid cancer have a favorable clinical course, some patients develop a more aggressive type of cancer and exhibit more rapid disease progression with worse prognosis. Those patients usually exhibit mutations of proteins such as tyrosine kinase enzymes that play a significant role in regulation of tumor proliferation and spreading. Development of targeted therapies is based on the inhibition of mutated kinases which are involved in the MAPK signaling pathway. The aim of this study was to present the initial results of clinical experience with kinase inhibitors in patients with metastatic differentiated thyroid cancer (DTC), poorly differentiated thyroid cancer (PDTC), and medullary thyroid cancer (MTC) who exhibited rapid disease progression. A total of 17 adult patients (11 women, mean age 53.3 years) managed for progressive, metastatic disease were included in the study. Twelve patients with DTC and PDTC were previously tested for BRAF mutations, of whom nine that had tumor tissue negative for the BRAF V600E mutation received sorafenib, while three patients with tumors harboring the BRAF V600E mutation were treated with vemurafenib. Patients with MTC were treated with sunitinib, vandetanib, and sorafenib. Two patients with tumors harboring the BRAF mutation treated with vemurafenib showed restoration of radioiodine uptake. Most of patients showed significant improvement in disease status but of limited duration until disease progression. Although there was an improvement in progression-free survival, future research has to achieve a greater and longer-lasting response, probably by utilizing combined targeted therapy.
\end{abstract}

Key words: thyroid cancer, tyrosine kinase inbibitors

\section{Introduction}

Patients with differentiated thyroid cancer (DTC) have a very good prognosis, with a 10 year-survival rate of more than $90 \%,{ }^{1,2}$ but that drops to only $10 \%$ in case of radioiodine refractory disease. ${ }^{3}$ Numerous patients with metastatic DTC have an indolent disease course and do not require systemic therapy. However, some

Corresponding author: Sanja Kusačić Kuna, Clinical Department of Nuclear Medicine and Radiation Protection, Zagreb University Hospital Centre, Kišpatićeva 12, 10000 Zagreb, Croatia

E-mail: sanja.kusacickuna@gmail.com patients have a more aggressive type of DTC with radioiodine-refractory progressive disease and a have worse prognosis. ${ }^{4}$ Those patients usually exhibit mutations in cell-signaling pathways, and many of the mutated proteins are kinase enzymes that play a significant role in the regulation of tumor proliferation, angiogenesis, invasion, and tumor spreading. Mutations of kinases included in the MAPK pathway lead to reduction of expression of genes included in iodine metabolism and subsequently dedifferentiation of thyroid cancer cells. ${ }^{5}$ Development of targeted systemic therapies is based on inhibiting mutated kinases which are 
involved in the MAPK signaling pathway. They can be inhibited with small-molecule kinase inhibitors (KI). When starting a treatment with $\mathrm{KI}$, the choice is between antiangiogenic multikinase inhibitors (MKI) that block multiple kinases with different targets (e.g. VEGFRs, RET, RET/PTC, EGFR) and more selective $\mathrm{KI}$ that require prior genetic testing for a specific mutation (e.g. for BRAF-directed therapy). There has been evidence in pre-clinical and clinical trials that MAPK pathway inhibitors lead to redifferentiation of thyroid cancer cells and restoration of radioiodine uptake. ${ }^{6-9}$

Poorly differentiated thyroid carcinomas (PDTC) represent $6 \%$ of all thyroid cancers. They are locally aggressive, metastasize early to the lungs and bones, and have a variable radioiodine uptake and poor prognosis. Many patients require systemic therapy with KI that is similar to therapy for DTC. 8,9

Medullary thyroid carcinomas (MTC) account for 3 to $5 \%$ of all thyroid cancers. In case of distant metastases, the 10 -year survival rate is only $20 \% .^{10}$ The most common genetic mutations in MTC are RET point mutations ${ }^{11}$, but there are no available selective RET kinase inhibitors that are approved for use yet.

Currently available kinase inhibitors have a high risk of serious side effects, especially MKIs (e.g. renal toxicity, hepatotoxicity, hypertension, myelosuppression, cardiotoxicity, cutaneous toxicity). Based on the above and on results of clinical trials in which kinase inhibitors only prolonged progression-free survival (PFS) but not overall survival (OS), ${ }^{12-15}$ patients have to be carefully selected before starting systemic therapy and need to be in active surveillance during treatment.

FDA and EMA approved sorafenib and lenvatinib for DTC and vandetanib and cabozantinib for MTC, and those kinase inhibitors are also approved by the Agency for Medicinal Products and Medicinal Devices of Croatia. However, at the time the therapy was initiated those drugs could not be prescribed at the expense of the Croatian Health Insurance Fund but were approved for the treatment of tumors other than thyroid cancer. Those drugs, as well as other KIs, were also available for off-label prescription according to literature evidence that they are effective and they will be mentioned in this study.

The aim of the study is to present the initial results of our clinical experience with kinase inhibitors in patients who exhibited rapid disease progression.

\section{Patients and methods}

Total of 17 adult patients (11 women; mean age 53.3 years at the time of disease detection) managed with kinase inhibitors since 2014 at the Clinical Department of Nuclear Medicine were included in this study: 9 with differentiated thyroid cancer (4 with papillary and 5 with follicular thyroid cancer, including Hürthle cell carcinoma), 3 with poorly differentiated thyroid cancer (one of them with both follicular and poorly differentiated cancer), and 5 with medullary thyroid cancer. All patients had progressive metastatic disease, and patients in the group with DTC and PDTC had radioiodine refractory disease. Twelve patients with DTC and PDTC were previously tested for BRAF mutations. Nine patients whose tumor tissue was negative for BRAF V600E mutation (75\%) received sorafenib therapy under special permission of the drug approval committee at the expense of the department where the patient was being treated. This medication is approved for use, but the cost of treatment is not covered by the Health Insurance Fund. Three patients with tumors harboring BRAF V600E mutation $(25 \%)$ out of a total of 12 tested patients were treated with vemurafenib in order to initiate restoration of radioiodine uptake. Patients with MTC were treated with sunitinib, sorafenib, and vandetanib (mainly through off-label use).

All patients were treated with some first-line kinase inhibitors until there were signs of significant disease progression on morphological imaging (MSCT) or until serious side effects occurred. In several patients, second- or even third-line treatment was introduced when considered clinically appropriate.

Our objective was to evaluate the efficacy of tyrosine kinase inhibitors and to determine the duration of response from beginning of treatment until the signs of disease progression, based on radiological assessment. The second goal was to present patients treated with vemurafenib and its influence on tumor redifferentiation. Finally, we wanted to point out side effects of these therapeutic agents.

\section{Results}

From 2014 until the beginning of 2020, a total of 17 patients were treated with kinase inhibitors at Clinical Department of Nuclear Medicine, Zagreb Univer- 
sity Hospital Centre. The results are divided into groups of patients as described below.

\section{DTC AND PDTC}

Twelve patients with DTC and PDTC (8 women, mean age 55.5 years; range $43-79$ ) received multiple radioiodine therapies after initial surgical resection, but in spite of initial treatment and radioiodine therapy they developed progressive metastatic disease that required systemic treatment with KIs for an average of 8.8 years after initial cancer diagnosis (range 1 to 22 years). There were 3 poorly differentiated insular cancers between them, while others had papillary and follicular cancer, including 2 Hürthle cell carcinoma. Most of the patients had metastases in the cervical lymph nodes and lungs (both 90.9\%), mediastinal lymph nodes and bones (both 54.5\%), but also in the brain (36.4\%), liver (27.3\%), and other sites such as the spleen, adrenal gland, kidney, and retina.

Nine patients whose tumors were negative for BRAF V600E mutation were treated with sorafenib as a first-line KI (daily dose of $800 \mathrm{mg}$ ). Among them, seven patients $(77.8 \%)$ had partial therapeutic response 3 months after initiating the treatment, but only four of them (44.4\%) had a prolonged response in further follow-up (mean 17.4, range 6-36 months) without disease progression. The other 3 patients had partial response after 3 months of treatment, as estimated by MSCT, but progressed shortly after the initial positive response and treatment was discontinued. One patient presented with disease progression at the first check-up after 3 months since initiating the treatment and died soon after. One patient had just started with the treatment while this report was being written but had to stop taking the drug after one month due to severe side effects (morphological evaluation was not yet performed). Two patients are still on treatment with sorafenib.

Three patients with DTCs harboring BRAF $\mathrm{V} 600 \mathrm{E}$ mutation were treated with vemurafenib (daily dose $960 \mathrm{mg}$ ) and two of them showed restoration of radioiodine uptake evaluated with I-131 imaging (Figure 1). One female patient from this group presented with progression of disease after 2 years of successful re-differentiation treatment with vemurafenib, which was then replaced by sorafenib as second-line treatment, but the patient died shortly after starting
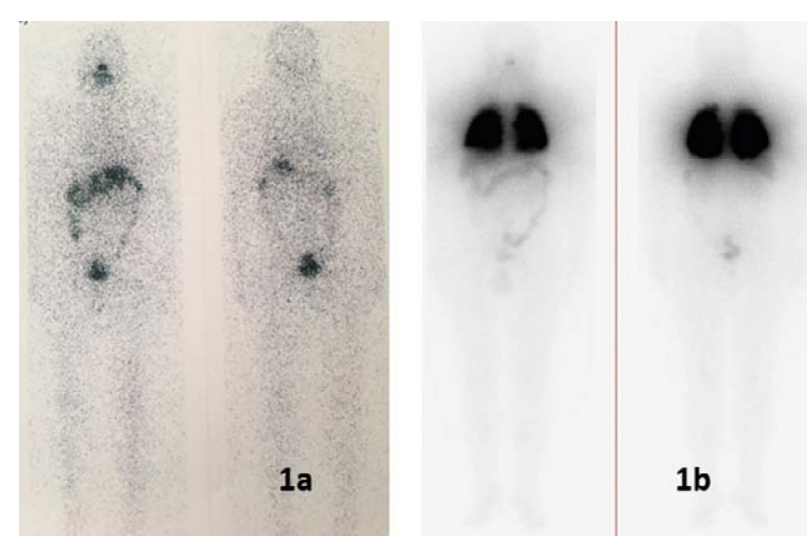

Figure 1. (a) Whole-body iodine-131 scan of patient demonstrating no visible uptake at the moment of disease progression with loss of previous well radioiodine accumulation, and (b) Whole-body scan of the same patient six months after vemurafenib therapy demonstrating intensive uptake in lung metastases (leading to redifferentiation of thyroid cancer cells and restoration of radioiodine uptake).

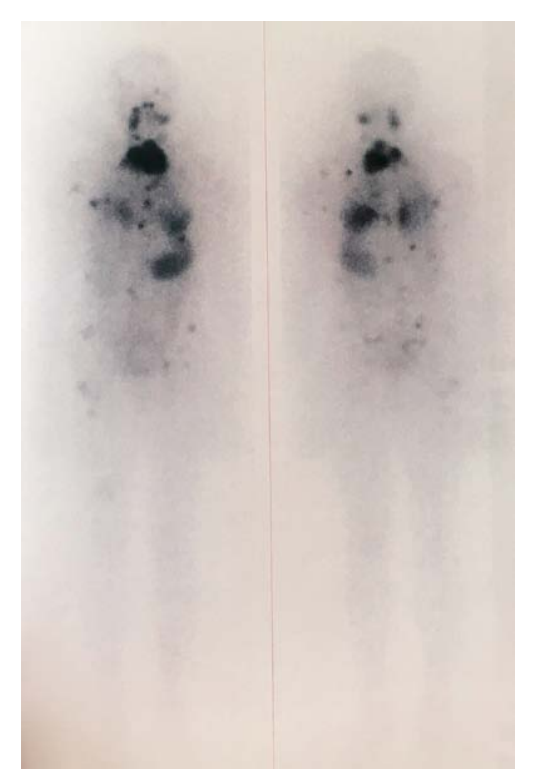

Figure 2. Whole-body iodine-131 scan of a patient with progressive disease and multiple metastatic lesions previously treated with vemurafenib.

the treatment (Figure 2). The third patient showed long-term improvement in lung status on morphological examination (MSCT) but did not want to perform a radioiodine scan.

Most patients who were negative for the BRAF mutation received sorafenib, which was introduced 


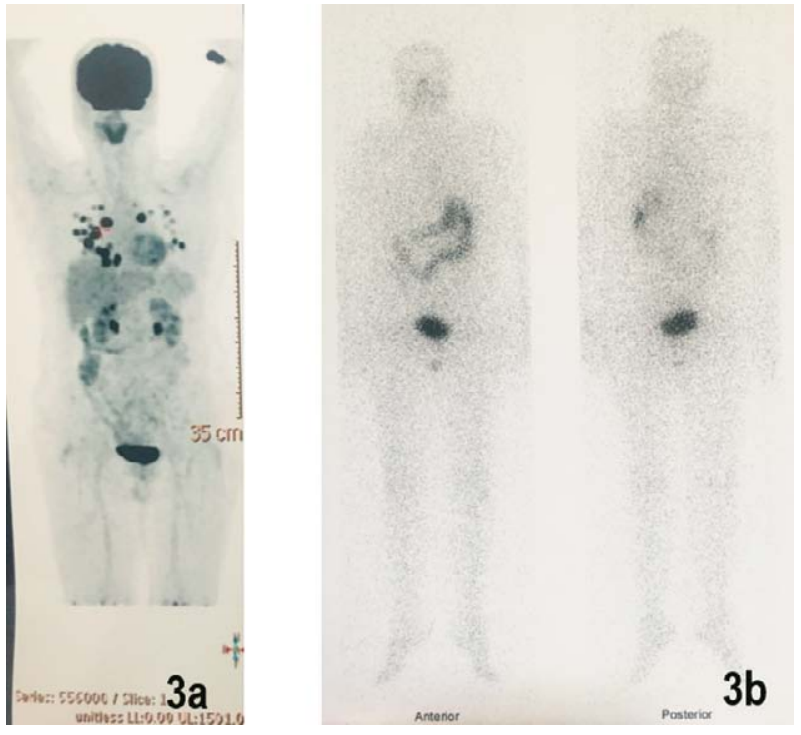

Figure 3. Extensive lung metastases accumulated ${ }^{18}$ F-FDG on PET/CT but did not accumulate iodine-131 in a female patient receiving sorafenib from 2015 to date, with occasional discontinuation of therapy.

when the disease progressed and extensive metastases accumulated fluorine-18-fluorodeoxiglucose on positron emission computed tomography $\left({ }^{18} \mathrm{~F}-\mathrm{FDG}\right.$ PET/ $\mathrm{CT}$ ) but did not accumulate iodine as it was in case of patient shown in Figure 3.

Some side effects were observed in all patients treated with sorafenib and vemurafenib. One of the primary adverse events experienced by patients with sorafenib was skin rash (8 patients), hand-foot skin reaction (5 patients), and mild diarrhea in some patients as well as weight loss and alopecia. One patient had stopped therapy with sorafenib because of extensive skin reaction as well as hoarseness. Two of nine patients $(22 \%)$ required daily dose reduction because of the side effects experienced during treatment with sorafenib, and in another two (22\%) it was necessary to withdraw sorafenib temporarily. Patients treated with vemurafenib developed squamous cell carcinomas of the skin (two of them), melanoma (pT1a in one patient), and keratoacanthomas (two of them). All three patients on vemurafenib therapy required occasional short-term dose reductions.

Six patients $(50 \%)$ from the group treated with sorafenib or vemurafenib died (five of them in the sorafenib group) on average 16.7 months after disease progression; range 6-28 months.

\section{$M T C$}

Five patients ( 3 women, mean age 48.2 ; range $36-$ 57 years) with progressive metastatic MTC started treatment with kinase inhibitors on average 8.2 years after cancer diagnosis (range 4 to 11 years). The most common metastatic sites in this group of patients were cervical lymph nodes (100.0\%), mediastinal lymph nodes (83.0\%), lung and bones (both 66.6\%), subcutaneous tissue $(50.0 \%)$, and other sites such as the liver, brain, skin, adrenal gland, and kidneys. Patients in this group received variable treatment options as a firstline treatment: sunitinib (daily dose $50 \mathrm{mg}$ ), vandetanib (daily dose $300 \mathrm{mg}$ ), and sorafenib (daily dose $800 \mathrm{mg}$ ). Patients were given the first drug available at that time, and if disease progressed, they were switched to the next drug from the group of tyrosine kinase inhibitors that was available. Most patients received sunitinib as first-line therapy because vandetanib was only later added to the list of drugs registered and approved for use on the Croatian market. Two patients (40\%) required second line treatment with sorafenib because of disease progression and finally even received third-line treatment with vandetanib.

In the group of 4 patients on first-line treatment with sunitinib, two of them (50\%) experienced partial response after 3 months of treatment as evaluated on morphological imaging (MSCT). Among them one female patient had a stable disease lasting 34 months from the introduction of therapy (but with shorter breaks in taking the drug due to side effects on the skin of the feet); another patient had stable disease for about 14 months from the introduction of sunitinib, but thereafter developed disease progression without significant efficacy of subsequently administered sorafenib and vandetanib and died about 2 years after disease progression. In one patient, sunitinib therapy was omitted during the second cycle of treatment due to gastrointestinal bleeding that could be associated with a tyrosine kinase inhibitor, but an intestinal polyp was subsequently also found. In this group, one patient developed fast progression that justified treatment discontinuation. Most patients had adverse effects during treatment that required dose reduction as well as temporary drug withdrawal, most common in the form of hand-foot skin reaction (80\%), but also nausea, hypocalcemia, and low complete blood count (CBC) were developed. 
One patient initially treated with vandetanib experienced partial response three months after introduction of treatment, but therapy was discontinued due to severe skin infection.

Three patients (60\%) from this group died (on average 21.7 months after disease progression; range 1130 months).

\section{Discussion}

Kinase inhibitors represent a novel systemic treatment option for patients with progressive metastatic thyroid cancer. Their efficiency was demonstrated both in clinical trials and retrospective studies. ${ }^{14-17}$ Some targeted agents (sorafenib, lenvatinib, vandetanib, cabozantinib) are approved by the FDA and EMA, and several other related agents are commonly used as off-label drugs for first- and second-line treatments. Because of potential serious toxicities as well as the high cost of these agents, treatment decisions should be made by experienced clinicians and patients should undergo close monitoring. ${ }^{15}$

Phase III of a multicenter, randomized, doubleblind clinical trial which studied sorafenib use in radioiodine refractory DTC (DECISION) showed improved PFS and response rates as compared with placebo by 10.8 months and 5.8 months, respectively. ${ }^{14}$ Similar improvements were also found in some retrospective studies. ${ }^{16-18}$ In our group of patients with DTC and PDTC treated with sorafenib, most patients had a partial response with a decrease in tumor mass, but unfortunately of limited duration, and none were completely cured.

Some patients with DTC develop radioiodine refractory disease and their median survival ranges from 3 to 6 years. ${ }^{3}$ Studies have shown that inhibition of the highly active MAPK pathway leads to redifferentiation of thyroid cancer cells and restoration of radioiodine (RAI) uptake. ${ }^{6-9}$ Two our patients treated with vemurafenib showed increased RAI uptake on a subsequently performed I-131 whole-body scan about six months after starting the treatment. One patient showed diffusely increased lung uptake and the other one showed increased RAI uptake in the lymph nodes of the neck and axilla and in the lungs, bones, and liver. Both subsequently received radioiodine therapy. One of them still has a stable disease as assessed on morphological imaging (six years from the start of treat- ment with vemurafenib), and the other patient had disease progression 2 years after starting the treatment and in the end died.

Patients with metastatic MTC often have aggressive disease resistant to standard chemotherapy., Two kinase inhibitors, vandetanib and cabozantinib, were recently approved by the FDA and EMA for treatment of progressive metastatic MTC. In two phase 3 clinical trials, ${ }^{12,13}$ both vandetanib and cabozantinib showed longer PFS compared with placebo (30.5 and 11.2 months, respectively), and both medications showed better disease control. Regarding sorafenib and sunitinib in this group of patients, their clinical benefit was also shown in several phase 2 studies. ${ }^{19-21}$ Most of our patients received sunitinib as a first-line therapy which resulted in a partial response or stable disease as in other trials. ${ }^{19,22}$ According to the literature, sorafenib and sunitinib could be considered for use in selected, advanced patients with MTC who cannot tolerate or who are not responsive to vandetanib or who are unable to participate in available clinical trials. ${ }^{19,21,23}$ However, vandetanib was used as first-line treatment in one case in our group of 5 patients, due to temporary problems during pre-registration of the drug because of a change of the licensed manufacturer. The other four patients with MTC were treated with sunitinib as a first-line KI and two of them (50\%) showed partial regression 3 months after initiation of treatment, as assessed with morphological imaging, with the regression being stable and of longer duration (in one patient lasting one year until further progression and another patient having stable disease for almost 3 years since the introduction of therapy). In one case, the disease progressed 3 months after approval for the use of the drug so sunitinib was omitted, and another patient had to stop the treatment with sunitinib due to development of possible side effects in the form of gastrointestinal bleeding shortly after introduction of drug. One patient who received vandetanib as the first-choice drug showed partial regression of tumor changes, but treatment was temporarily discontinued due to a skin infection in form of papulopustular rash which has also been described as a potential side effect in the literature. ${ }^{24,26}$ Two patients who received vandetanib as the third- or second-line therapy showed partial response of short duration in further follow-up.

Adverse effects were present in all of our patients treated with kinase inhibitors. The most frequent ad- 
verse events in the sorafenib group were rash or desquamation, hand-foot skin reaction, diarrhea, and alopecia, which is similar to other studies. ${ }^{14}$ Some side effects required temporary drug withdrawal (31.2\%) and some required dose reductions (29.4\%). This is similar to results of clinical trials and retrospective studies. ${ }^{17,18,22,23}$ One patient in our study developed gastrointestinal bleeding during sunitinib therapy, which is a possible side effect of the therapy. Hemorrhage has been reported in the literature with certain agents, and one of the sunitinib trials reported a $14 \%$ rate of GI bleeding, including one grade 5 event. ${ }^{19}$ There were no deaths attributable to drug side effects. All the patients on vemurafenib developed either squamous cell carcinoma of the skin, melanoma, or keratoacanthoma during treatment. Studies have demonstrated greater incidence of both benign and malignant skin lesions during treatment with BRAF inhibitors. $^{23}$

Generally speaking, none of these drugs leads to a general cure of the disease, and it is important to weigh the risks and benefits of treatment. If the natural course of metastatic DTC is a slowly progressing disease, the risk of adverse events of TKI therapy as well as their cost outweigh the potential benefit of those drugs. Therefore, the patients must present with at least progressive disease within one year before the initiation of targeted therapy. ${ }^{24,25}$ Furthermore, TKI should not be used in patients with only increased calcitonin and CEA in the blood and no structural evidence of disease or patients with small tumor masses without any evidence of progression on imaging studies, patients who are generally asymptomatic, or who have multiple comorbidities. ${ }^{26}$ Currently, no precise data strongly support the first-line selection of one agent over another. Individualized selective introduction of targeted therapies depends on the availability of these drugs in the institution that treats thyroid cancer, but should be based on the main goal of treatment, potential side effects, and the patient's response. ${ }^{27}$

\section{Conclusion}

Treatments with kinase inhibitors in patients with progressive metastatic thyroid cancer are being prescribed at an increasing rate. There has been an improvement in progression-free survival with new ki- nase inhibitors, but a future goal would be to achieve greater, longer lasting, and more likely response, probably by utilizing combined targeted therapy. According to preclinical and clinical trials, inhibition of highly active MAPK pathway in patients with DTC could induce redifferentiation of tumors and lead to recovery of radioiodine uptake in cancer cells. This would lead to possible of application of radioiodine therapy that could be helpful in improved control of progressive metastatic disease.

\section{References}

1. Hundahl SA, Fleming ID, Fremgen AM, Menck HR. A National Cancer Data Base report on 53,856 cases of thyroid carcinoma treated in the U.S., 1985-1995. Cancer 1998; 83: 2638-2648.

2. Kusić Z, Prgomet D. Karcinom štitne i doštitne žljezde. In: Prgomet D. Tumori glave i vrata. Zagreb: Medicinska naklada. 2019.p. 262-73. Croatian

3. Durante C, Haddy N, Baudin E, Lebolleux S, Hartl D, Travagli JP, et al. Long-term outcome of 444 patients with distant metastases from papillary and follicular thyroid carcinoma: benefits and limits of radioiodine therapy. J Clin Endocrinol Metabol 2006; 91(8): 2892-9.

4. Prgomet D, Bilić M, Kovac L, Hutinec Z, Topić I. Locally invasive papillary thyroid cancer--our experience. Lijec Vjesn. 2012 Sep-Oct;134(9-10):266-70. Croatian

5. Durante C, Puxeddu E, Ferretti E, Morisi R, Morreti S, Bruno $\mathrm{R}$, et al. BRAF mutations in papillary thyroid carcinomas inhibit genes involved in iodine metabolism. J Clin Endocrinol Metab 2007; 92: 2840-2843.

6. Chakravarty D, Santos E, Ryder M, Knauf JA, Liao XH, West $\mathrm{BL}$, et al. Small-molecule MAPK inhibitors restore radioiodine incorporation in mouse thyroid cancers with conditional BRAF activation. Journal of Clinical Investigation 2011; 121:4700-4711.

7. Ho AL, Grewal RK, Leboeuf R, Sherman EJ, Pfister DG, Deandreis D, et al. Selumetinib-enhanced radioiodine uptake in advanced thyroid cancer. New England Journal of Medicine 2013; 368: 623-632.

8. Rothenberg SM, McFadden DG, Palmer EL, Daniels GH, Wirth LJ. Redifferentiation of iodine-refractory BRAFV600Emutant metastatic papillary thyroid cancer with dabrafenib. Clin Cancer Res 2015; 21:1028-1035.

9. Dunn LA, Sherman EJ, Baxi SS, Tchekmedyian V, Grewal RK, Larson SM, et al. Vemurafenib redifferentiation of BRAF mutant, RAI-refractory thyroid cancers. Journal of Clinical Endocrinology and Metabolism 2019; 104: 1417-1428.

10. Modigliani E, Cohen R, Campos JM, Conte-DevolxB, Maes $\mathrm{B}$, Boneu A, et al. Prognostic factors for survival and for biochemical cure in medullary thyroid carcinoma: results in 899 
patients. The GETC Study Group. Groupe d'etude des tumeurs a calcitonine. Clin Endocrinol 1998; 48: 265-273.

11. Wells SA Jr, Robinson BG, Santoro M, Pacini F. Multiple endocrine neoplasia type 2 and familial medullary thyroid carcinoma: an update. J Clin Endocrinol Metab 2013;98: 3149-3164.

12. Wells SA Jr, Robinson BG, Gagel RF, Dralle H, Fagin JA, Santori $\mathrm{M}$, et al. Vandetanib in patients with locally advanced or metastatic medullary thyroid cancer: a randomized, doubleblind phase III trial. J Clin Oncol 2012; 30: 134-141.

13. Elisei R, Schlumberger MJ, Muller SP, Schoffski P, Brose MS, Shah $\mathrm{MH}$, et al. Cabozantinib in progressive medullary thyroid cancer. J Clin Oncol 2013; 31: 3639-46.

14. Brose MS, Nutting CM, Jarzab B, Elisei R, Siena S, Bastholt L, et al. Sorafenib in radioactive iodine-refractory, locally advanced or metastatic differentiated thyroid cancer: a randomised, double blind, phase 3 trial. Lancet 2014; 384: 319-328.

15. Lirov R, Worden FP, Cohen M. The treatment of advanced thyroid cancer in the age of novel targeted therapies. Drugs 2017; 77: 733-745.

16. Cabanillas ME, Waguespack SG, Bronstein Y, Williams MD, Feng L, Hernandez M, et al. Treatment with tyrosine kinase inhibitors for patients with differentiated thyroid cancer: the M. D. Anderson experience. J Clin Endocrinol Metab 2010; 95: 2588-2595.

17. Molina-Vega M, Garcia-Aleman J, Sebastian- Ochoa A, Mancha-Doblas I, Trigo-Perez JM, Tinahones-Madueno F, et al. Tyrosine kinase inhibitors in iodine-refractory differentiated thyroid cancer: experience in clinical practice. Endocrine 2018; 59: 395-401.

18. Sousa Santos F, Joana Santos R, Leite V: Sorafenib and Sunitinib for the Treatment of Metastatic Thyroid Cancer of Follicular Origin: A 7-Year Single-Centre Experience. Eur Thyroid J 2019; 8:262-267.
19. Carr LL, Mankoff DA, Goulart BH, Eaton KD, Cappel PT, Kell EM, et al. Phase II study of daily sunitinib in FDG-PETpositive, iodine-refractory differentiated thyroid cancer and metastatic medullary carcinoma of the thyroid with functional imaging correlation. Clin Cancer Res 2010; 16: 5260-5268.

20. Cohen EE, Needles BM, Cullen KJ, Wong SJ, Wade JL, Ivy SP, et al. Phase 2 study of sunitinib in refractory thyroid cancer. J Clin Oncol 2008; 26 (Suppl) 6025 (abstr).

21. Lam ET, Ringel MD, Kloos RT, Prior TW, Knapp MV, Liang J, et al. Phase II clinical trial of sorafenib in metastatic medullary thyroid cancer. J Clin Oncol 2010; 28: 2323-2330.

22. Ravaud A, de la Fouchardiere C, Caron P, Doussau A, Do Cao $\mathrm{Ch}$, Asselineau J, et al. A multicenter phase II study of sunitinib in patients with locally advanced or metastatic differentiated, anaplastic or medullary thyroid carcinomas: mature data from the THYSU study. Eur J Cancer 2017; 76: 110-117.

23. Brose MS, Cabanillas ME, Cohen EE, Wirth LJ, Riehl T, Yue $\mathrm{H}$, et al. Vemurafenib in patients with BRAF(V600E)-positive metastatic or unresectable papillary thyroid cancer refractory to radioactive iodine: a non-randomised, multicentre, open-label, phase 2 trial. Lancet Oncol 2016; 17: 1272-1282.

24. Iwasaki H, Yamazaki H, Takasaki H, Suganuma N,Sakai R, Nakayama H, et al. Treatment outcomes of differentiated thyroid cancer with distant metastasis improve by tyrosine kinase inhibitors. Oncol Lett 2019; 17: 5292-5300.

25. Herceg D, Horvatić Herceg G. Targeted therapy in patients with radioiodine-refractory differentiated thyroid cancer (DTC). Period biol 2014; 116, 399-407.

26. Kim BH, Kim IJ. Recent Updates on the Management of Medullary Thyroid Carcinoma. Endocrinol Metab 2016; 31: 392-399.

27. Gruber JJ, Colevas D. Differentiated Thyroid Cancer: Focus on Emerging Treatments for Radioactive Iodine-Refractory Patients. The Oncologist 2015;20:113-126. 


\title{
Sažetak PRIMJENA INHIBITORA KINAZA
U LIJEČENJU BOLESNIKA S UZNAPREDOVALIM RAKOM ŠTITNJAČE
}

\author{
Matea Pešorda, Sanja Kusačić Kuna, Dražen Huic, Davorin Herceg, Marija Despot, \\ Tatjana Samardžić, Milena Gnjidić i Borislav Belev
}

Iako većina bolesnika s karcinomom štitnjače ima povoljan klinički tijek, ipak neki bolesnici pokazuju agresivniji tijek bolesti s razvojem uznapredovalih formi tumora i lošijom prognozom. Razlog su vjerojatno mutacije proteina, uglavnom enzima tirozin kinaza koji imaju značajnu ulogu u proliferaciji i rastu tumora. Razvoj ciljanih terapija zasnovan je na inhibiranju mutiranih kinaza BRAF, MEK, NRAS, c-KIT koje su uključene u signalni put MAPK. U radu su predstavljeni preliminarni rezultati liječenja inhibitorima kinaza u bolesnika s metastatskim diferenciranim karcinomom štitnjače (DTC), slabo diferenciranim karcinomom štitnjače (PDTC) i medularnim karcinomom štitnjače (MTC). U izvješće je uključeno ukupno 17 odraslih bolesnika (11 žena, prosječna dob 53,3 godine) liječenih zbog progresivne, metastatske bolesti. Dvanaest bolesnika s DTC i PDTC prethodno je testirano na BRAF mutacije. Devet bolesnika kod kojih je tumorsko tkivo bilo negativno na mutaciju BRAF V600E primali su sorafenib, dok su tri bolesnika s tumorima koji nose mutaciju BRAF V600E liječena vemurafenibom u cilju rediferencijacije tumora, a u dva bolesnika došlo je do ponovne akumulacije radiojoda na scintigramu tijela. Bolesnici s MTC-om liječeni su sunitinibom, vandetanibom i sorafenibom. U većine bolesnika došlo je do pozitivnog terapijskog odgovora uz poboljšanje stanja, ali ograničenog trajanja. Buduća istraživanja bi trebala osigurati bolji i trajniji terapijski odgovor, vjerojatno primjenom kombinirane ciljane terapije.

Ključne riječi: karcinom štitnjače, inbibitori tirozin kinaza 